\title{
E-government Implementation in Spain, France and Russia: Efficiency and Trust Level
}

\author{
E.P. Boldyreva ${ }^{1}{ }^{*}$, N.V. Gorbunova ${ }^{1}, T . Y u$. Grigoreva $^{1}$ and E.V. Ovchinnikova ${ }^{1}$ \\ *Corresponding author: k_e_p@mail.ru \\ ${ }^{1}$ Saratov Socio-Economic Institute of Plekhanov Russian University of Economics, Saratov, Russia
}

\begin{abstract}
The article considers peculiarities of modern information technologies introduction including e-state management (e-government) in government bodies, local authorities and governmental structure. Certain factors, influencing citizen's intention to use the system of interaction with e-government, taking into account trust, perceived risk and political efficiency on the example of several European countries are described in the article. Attempt to compare different approaches to e-government introduction into countries, having basic differences, influencing e-government introduction, i.e. cultural and historic problem of the country, infrastructure, e-competence and development of citizens, civil servants and technical staff was made by the authors. Advantages of e-government, such as improvement of access to information and services; dropping-out of access limits to authority, improvement the quality of service and reputation; integration of institutions are revealed in the paper. The authors attempt to examine modern conditions of new information technologies introduction; determine anticipated utility of their use; obtain new data of new government services; generalize problems of anticipated risks and threats for citizens, using e-government services and contemplate ways of their prevention.
\end{abstract}

Keywords: e-government, information technologies, trust, anticipated risks.

\section{Introduction}

E-government means application of information and communicatory technologies for improvement of government sector activity. This is a new form of government interaction and collaboration of government and citizens, state and industry, between governmental bodies. E-government is supposed not only to help the state to fulfil its everyday administrative activity, but also to provide an easier way of interaction with citizens and enterprises using information and communicatory technology (ICT) [1]. E-government is defined as the implementation of information technologies able to transform relations with citizens, business and other important structures by the government [2]. These technologies can serve different purposes: improve interaction with business and citizens via provision of free access to information; make governmental services more available for society and, therefore, serve more effective management [3]. It results in reduced corruption, more visualized interaction and cost reduction.

\section{Problem Statement}

We aim at the investigation of the following issues: 1) to study factors, influencing citizen's intention to use system of interaction with e-government through ICT; 2) to define such notions as "trust", "anticipated risk" and "political efficiency"; 3) to reveal advantages, suggested bye-government and to examine the problem of dropping-out access limits of citizens to the government; 4) to contemplate possibilities of inexpensive and effective e-government service improvement and to reveal ways of improving authority reputation.

\section{Research Questions}

Under conditions of information society development, we are worried about the issue of how big the influence of information technologies on political process, life of society and every one of us is. No doubt, new information technologies are able to considerably improve living standard, social relations, and government management. However, the process of new information technologies introduction was not that simple. Taking into consideration researches published earlier, it is possible to state that e-government was not always successful at the introduction level. Some researches prove that it is more effective in developed countries, rather than in developing [4]. Comparative study of egovernment introduction between developed and developing countries revealed basic differences, influencing plans of its introduction. Among them are historic and cultural problems of the country; technical staff competence; infrastructure of the state; e-competence and development of citizens, civil servants; moral values of citizens; personality resource and its importance for professional environment and socialization. We would like to access data of research issues on the analysis of information about problems having arisen during e-government introduction in Spain, France and Russia. 
Starting our analysis in alphabetical order, we would begin with Spain, which in comparison with other European countries, in the end of 1990s was estimated as having rather low level of Internet diffusion and its low prevalence among Spanish citizens. The majority of people in Spain, having Internet access and able to use it, were educated men, located in central part of the country and were aged 30-39 years. One of the reasons of rare internet use was due to the lack of library and informational systems (LIS). So, because of this fact, the number of published works on these issues had increased from one at the beginning of the decade to twenty-two in 1999. In Spain there were no Bachelor's degree and Doctoral Post graduate programs in information sciences up to 1990s. There was no time to prepare a considerable number of specialists in the field of information technologies and increase society's demand for informatization in the country. There was a lack of specialists in the field of national policy elaboration of informatization and population enlightenment of new information and communicatory technologies. Academic sphere worked on creation of ICT model implementation by students and teaching staff, but no attention was paid to ICT model implementation by citizens in everyday life. Study of published works of Spanish scientists in the period of 1990s to 2005 showed that ICT model implementation lack behind people's and society's needs, as it is seen from low volume of published research works and conferences inside the country on the above mentioned issues.

Despite the fact, that Spain aimed to participate in international dialogue on ITC issues, e-government and information policy, the lack of educated specialists in informatization sphere in combination with government, having limited possibility to inform citizens, lead to the fact that Spain was considered a "developed" country, but judging by information structure condition, it was rather a "developing" one. Information quality consideration on Spanish city council's web-sites of that time period proves that digital information transparency of city councils was very poor. Politicians perceived existence in the Internet as secondary aim, probably thinking that citizens do not have enough interest or awareness in this issue to understand the content of economic information published by administration.

Entering the 21st century, Spain seriously started to work on issues connected with information infrastructure and information policy development. During previous decade the so-called army of informatization specialists was created, ready to examine information needs of Spain and find out how real those needs satisfied and what kind of information policy is important to implement in future. Apart from that, people were taught to apply ICT skills as part of obligatory education program, mainly with the help of public Libraries. Since the end of 2015 in Spain a number of laws concerning government sector have been implemented, influencing documentation turnover management [5]. The most important change, introduced by these laws, states that mechanism of e-government and, therefore, e-procedure are the only single possible ways of interaction. Paper documents are omitted and could be used only in some very special cases. As a result, Spain now occupies the seventeenth place in UNO e-government rating of 2018.

As for France, this country started process of digitalization much earlier and faster and in the same UNO egovernment rating of 2018 year occupies ninth place, being one of governments-leaders in implementation of egovernment services. So, the aim of e-government implementation is to inform citizens of the country and inspire them to obtain e-government services [6]. Due to this, Governmental policy modernization Board was formed in 2009 in France. Chaired by President of the Republic this Board united all state Ministries, taking decision on necessity of reforms in some areas, connected with French government modernization. Board competences include e-government development issues and quality of governmental information system issues. Budget Minister of France heads the General Directorate of government modernization. It is organized to combine e-government development and government modernization policy, and touches on such issues of e-government, as improvement of government management and rendering of public services. It renders three main services:

1. "Innovation" service - works out measures and strategies for simplification and modernization of public services for citizens, enterprises and local authorities.

2. "Consultancy" service - helps Ministries to implement solutions, made by Governmental policy modernization Board.

3. "Project" service - is responsible for implementation of interdepartmental projects, connected with quality of egovernment services, improvement of customs service and e-government development.

General Directorate of government modernization is in charge of management and monitoring e-government programs implementation and interdepartmental projects (excluding Government service portal, managed and supplied by French Documentation Office at the Government Publishing House). Data protection is provided by National computer science and freedom committee. Regional and local authorities should develop corresponding local strategies of e-government policy in accordance with the national policy. General Directorate of state modernization supports this activity and Caisse des Dépôts, state financial body, encourages the local e-government performance as well by creating secure infrastructure of legally binding electronic documents exchange. Caisse des Dépôts Syndication Office let the local and regional authorities to be enriched with the broad scope of electronic information and data services received for national electronic government.

Meanwhile citizens' trust level to e-government is surprisingly high. It is very important and positive factor as most researchers are harmonious in questions about trust - it is concerned to be highly influencing the cooperation and public activity in any state. Myles and Popper define trust as promises individuals can rely on. In the course of research work there were two categories developed: trust and trust basis establishment. The characteristics of trust are interrelated with personal trait of citizens, for example with age, race, gender, nationality etc [7].

In Russia e-government establishment was based on the experience of European countries but still has its own way. The detailed comparison of the Russian project goals and the goals of foreign campaigns shows the difference in approaches: foreign campaigns are created to satisfy citizens' needs through modernization of authorities/bodies with the 
introduction of improved ICT; the Russian approach is directed to modernization of governmental bodies through the introduction of ICT [8]. That is, the means used in foreign strategies as the instruments are accepted as the anticipated result in the Russian policy [9].

In the 2018 United Nations rating of e-government development level Russia was on the $32^{\text {nd }}$ place improving the result from $35^{\text {th }}$ place in 2016. For implementing the e-government system special program was adopted - "Electronic Russia (2001-2010)". Later in 2009-2010 plans to transfer state and municipal services in electronic mode were accepted as the main objective within the frame of e-government implementation. At the same time formation and precise priority definitions of new state program "Information society (2011-2020)" were originated.

Today the creators of Russian electronic government are constantly solving the questions of access to information, level of its reliability and benefits for citizens. They have to make constant follow-ups concerning citizens' needs and attitude in order to develop those issues of e-government which seem to be necessary for improving the work and reliability of the whole system and some specific services [10]. Reliability and trust questions became the central and burning issues in all everyday interactions and transactions especially if we speak about remote access through the Internet. Trust level can become the main factor encouraging the citizens to use e-government system as the trust to the state and the governmental system is interrelated with the confidence of a person to get high quality services online [11]. The 2018 rating of electronic state services in Moscow region can be taken as an example: the first place went to an electronic diary of a pupil and more than 21 million people wanted to find out the marks of a child. The second place was taken by service of indication the water and gas indexes - more than 3 million people used it. The third place was granted to the electronic queue and one million people applied to it. The issue of the uniform payment document (UPD) appeared on the fourth place with audience of 1310000 users. The 5th place goes to special service of monitoring pupils pass and food at schools canteens - 87 thousand people were interested in this service [12]. Safe access and use of a "private account" is highly appreciated by citizens of Russia.

Safety issues, confidentiality and Internet fraud caused huge concern of citizens while adopting the e-government and new technologies. The whole range of questions about information risks and threats is designed to investigate universal introduction of modern information technologies, including electronic public administration (the electronic government) in public authorities and local government. In this regard information about the services provided by the egovernment on the Internet has to be accompanied with the special explanation to citizens about the way they are carried out. A number of researchers consider that users hope that web technologies depend on network safety, confidentiality and information reliability.

Thus, it is necessary to form citizens' confidence in e-government [13]. Trust is a significantly necessary factor and actually means that e-government has to undertake all possible actions to eliminate the risks and the level of vulnerability. If there was no risk, we could possibly speak about full confidence of citizens and their high trust to e-government [14].

The question about political efficiency as a factor which encourages formation of trust while establishing the interaction with e-government is particularly burning issue. The political efficiency can be divided into two types symbolically.

First, it is internal political self-sufficiency of the citizen when he/she understands that he/she makes a real contribution and has influence on political development. Secondly, external political efficiency which is perceived by the citizen as the e-government response level to the realization of citizens needs [15]. Political efficiency factor has considerable influence and helps to form citizens' general trust to e-government. In its turn, the government, taking it into account, has to react quickly to the citizens' needs and improve rendering electronic services to individuals.

\section{Purpose of the Study}

The purpose of this research is to understand and estimate anticipated use of e-government, to receive clearer picture of its occurrence, to study historical and current stages of its implementation. The ways of citizens' involvement into democratic participation in government are assessed, considering the factors of trust and the actual risks, trying to use the experience of some foreign countries.

\section{Research Methods}

To receive a full picture about the current implementation of e-government, it is necessary to investigate how effectively it is used by citizens. While making the research we applied a number of methods. First, a method of the comparative analysis which is based on the critical analysis of earlier published sources considering questions of egovernment introduction.

Thereby for a research of a problem the research base which is conceptually relying on the previous works was taken. Secondly, a number of methods for clarification of the current situation: method of the analysis and synthesis, statement of a problem, collecting departmental data/reports, web monitoring of the websites (federal website of public services gosuslugi.ru; local authorities websites providing public services to its inhabitants; specialized websites of the multipurpose centers, systems of rendering public services). 


\section{Findings}

On the basis of the conducted research it is possible to draw the following conclusions. While implementing the electronic government it is important to make a research about interaction of the e-government and citizens as it will reflect the progress and current success. These types of research work serve for studying of the factors influencing citizens' intention to use electronic system taking into account such moments as trust, the anticipated risk and political efficiency.

The e-government is not always introduced successfully. It is effective in developed, but not in developing countries, as there are main distinctions influencing implementation plans: cultural and historical problems of the country, infrastructure, electronic readiness and development of citizens, public servants, technicians.

Degree of trust and anticipated risk can be factors accompanying citizens' intentions to use the e-government system. Trust is the central problem in all daily interactions, operations and practice, communication, especially when all this is carried out remotely, via the Internet. However there is no consensus about how to measure citizens' trust level to the government, how to achieve this trust, why it can be lost. Most of researchers agree that trust is the most important factor defining cooperation and public actions.

Trust basis rests on the previous experience of the person with the government [16]. Positive trust level can be reached if the government is able to provide proper implementation of the e-government and its work. At the same time, to maintain a high level of safety the technologies applied have to be carefully developed before the moment of its implementation. Encouragement and conviction are the most important factors for creating needed infrastructure: citizens should realize and believe that they will gain the same positive experience of interaction with e government which was accumulated previously with traditional system. It is necessary for a person to feel confident in a new environment, to understand that this innovative technology is reliable and safe. The trust of citizens to the Internet is defined as the main sign of e-government acceptance. This type of trust connected with establishment of trust to communities which exist on the Internet varies depending on norms, expectations and their value. The trust to the egovernment is connected with citizens' confidence in its ability to render high-quality services online. Information on the services provided by the government via Internet has to be followed by explanation to citizens on the way they are delivered. With the adoption of the electronic government and new technologies the citizens are concerned with confidentiality, safety and frauds on the Internet. The anticipated risk is supposed to decrease when the trust level increases. Anticipated risk is a citizen's innate expectation of sufferings from loss in the process of desirable result search. The trust should be considered as a determinant mark of individual intention to use the offered services, knowing or assuming existence of risk. Political efficiency is considered to be the most important factor which encourages formation of citizens' trust concerning the problem of e-government interaction establishment.

\section{Conclusion}

To receive a full picture about e-government concept implementation we need: to continue research on how effectively services of the electronic government are used by citizens; to define anticipated usefulness of its use; to study current state of introduction of new information technologies; to avoid possible risks for citizens at their use, relying on the international experience of the e-government implementation.

To achieve these goals expert surveys, polls, methods of "test purchases" should be conducted. Various web monitoring instruments should be applied as well to control and assess public and municipal services, activity of the multipurpose centers etc. Departmental and other reporting data should be collected to analyze problems of electronic government development.

\section{References}

1. C.S. Browning, M.McDonald, The future of critical security studies: Ethics and the politics of security. European Journal of International Relations, 19(2), 235-255. DOI: 10.1177/1354066111419538 (2013).

2. T.S. Melnikova, N.V. Mityaeva, A.M. Petrov, A.D. Bobkova, Mechanism to underpin state patronage of novel public goods: revisiting the theory of effective manipulation. Regional Science Inquiry, 9(2), 69-84 (2017).

3. K. Abbink, J. Brandts, Political autonomy and independence: Theory and experimental evidence. Journal of Theoretical Politics, 28(3), 461-496. DOI: 10.1177/0951629815571150 (2016).

4. S.V. Volodenkov, Tekhnologii bigdata $\mathrm{v}$ sovremennikh politicheskih protzessakh: tzifrovie vizovi I ugrozi. Vestnik Tomskogo Gosudarstvennogo Universiteta. Filosophia. Soziologiya. Politologiya, 44, 205-212. URL: http://journals.tsu.ru/philosophy/\&journal_page==archive\&id=1738\&article_id=38687 (2018). [in Rus.].

5. J. Freedman, Status insecurity and temporality in world politics. European Journal of International Relations, 22(4), 797-822. DOI: 10.1177/1354066115603781 (2015).

6. A.A. Moiseeva, Usloviya i posledstviya didgitalizatzii sovremennogo obshestva: sozialno-ekonomicheskii analiz. Vestnik Tomskogo Gosudarstvennogo Universiteta. Filosophia. Soziologiya. Politologiya, 39, 216-226. URL: http://journals.tsu.ru/philosophy/\&journal_page=archive\&id=1628\&article_id=36531 (2017). [in Rus.]. 
7. J. Myles, R. Popper, Tekhnologii informatsionnogo obschestva i evropeiskiye tseli. Forsight, 1(5), 52-59 (2008). [in Rus.].

8. V.B. Belov, Tzifrovaya povestka Rossiisko-germanskoi khozyaistvennoi kooperatzii. Sovremennaya Evropa, 2(81), 120-128. DOI: 10.15211/soveurope22018120128. (2018). [in Rus.].

9. N.S. Yashin, T.A. Andreeva, A.V. Serebrjakov, N.G. Bagautdinova, Implementation of the strategy: Problems and solutions. Mediterranean Journal of Social Sciences, 6(1), 475-480. DOI: 10.5901/mjss.2015.v6n1s3p475 (2015).

10. E.V. Lobza, D.O. Bortvin, R.R. Hasanshin, Otsenka innovatsionnogo potentsiala cherez prizmy indikatorov razvitiya informatsionnogo obschestva i ekonomiki znanii. Vestnik Mezdunarodnyh Organizatsiy: Obrazovaniye, Nauka, Novaya Ekonomika, 1, 33-50 (2010). [in Rus.].

11. A.A. Korobov, E.P. Boldyreva, Politicheskaya propaganda v sovremennoi telekommunikatsionnoi srede: mehanizmy povysheniya effektivnosti. Vestnik Povolzckogo Institute Upravleniya, 18(3), 96-105. DOI: 10.22394/1682-2358-2018-396-105 (2018). [in Rus.].

12. Officialnoe zayavlenie Ministerstva tzifrovogo razvitiya, svyazi i massovyh kommunikatzii Rossiyskoy Federatzii ot 08.02.2018. Retrieved from: https://digital.gov.ru/ru/events/37879/. Accessed: 04.01 .2019 (2018). [in Rus.].

13. D.M. Konisky, M.P. Teodoro, When governments regulate governments. American Journal of Political Science, 60(3), 559-574. DOI: 10.1111/ajps.12221 (2016).

14. M. Albertus, V. Gay, Unlikely democrats: Economic elite uncertainty under dictatorship and support for democratization. American Journal of Political Science, 61(3), 624-641. DOI: 10.1111/ajps.12277 (2017).

15. I. Manakhova, E. Limonova, Socioeconomic leadership of the individual in the information economy: Nanolevel of research. In W. Strielkowski \& O. Chigisheva (Eds.), Leadership for the Future Sustainable Development of Business and Education. Springer Proceedings in Business and Economics (pp. 551-558). Springer, Cham. DOI: 10.1007/978-3-319-74216-8_55 (2018).

16. S. Gehlbach, A. Simpser, Electoral manipulation as bureaucratic control. American Journal of Political Science, 59(1), 212-224. DOI: 10.1111/ajps.12122 (2015). 